\title{
INTERRUPTING CHAGAS DISEASE TRANSMISSION IN VENEZUELA
}

\author{
Alberto ACHÉ (1) \& Alí J. MATOS(2)
}

\begin{abstract}
SUMMARY
The interruption of vectorial transmission of Chagas disease in Venezuela is attributed to the combined effects of ongoing entomoepidemiological surveillance, ongoing house spraying with residual insecticides and the concurrent building and modification of rural houses in endemic areas during almost five decades. The original endemic areas which totaled $750,000 \mathrm{~km}^{2}$, have been reduced to $365,000 \mathrm{~km}^{2}$. During 1958-1968, initial entomological evaluations carried out showed that the house infestation index ranged between $60-80 \%$, the house infection index at $8-11 \%$ and a house density index of 30-50 triatomine bugs per house. By $1990-$ 98 , these indexes were further reduced to $1.6-4.0 \%, 0.01-0.6 \%$ and 3-4 bugs per house respectively. The overall rural population seroprevalence has declined from $44.5 \%$ (95\% C.I.: 43.4-45.3\%) to 9.2\% (95\% C.I.: 9.0-9.4\%) for successive grouped periods from 1958 to 1998 . The annual blood donor prevalence is firmly established below $1 \%$. The population at risk of infection has been estimated to be less than four million. Given that prevalence rates are stable and appropriate for public health programmes, consideration has been given to potential biases that may distort results such as: a) geographical differences in illness or longevity of patients; b) variations in levels of ascertainment; c) variations in diagnostic criteria; and d) variations in population structure, mainly due to appreciable population migration. The endemic areas with continuous transmission are now mainly confined to piedmonts, as well as patchy foci in higher mountainous ranges, where the exclusive vector is Rhodnius prolixus. There is also an unstable area, of which landscapes are made up of grasslands with scattered broad-leaved evergreen trees and costal plains, where transmission is very low and occasional outbreaks are reported.
\end{abstract}

KEYWORDS: Chagas disease; Endemic; Prevalence; Triatomine bugs; Residual insecticides; Infestation; Surveillance.

\section{INTRODUCTION}

Chagas disease was first described in Venezuela in $1919^{15}$. Very soon after it ranked amongst the first five causes of death annually for almost three decades. However, as from 1980, the disease has fluctuated between the thirteenth and eighteenth position, with 600 to 840 deaths as registered by annually vital statistics reports ${ }^{11}$. A course of events has contributed to its sustained declination as a public health problem. First, with the introduction of DDT as from December 2, 1945. This insecticide made an important impact on many insect populations and was then used for widespread and sustained indoor house spraying activities in a national campaign against malaria. It was then followed by the introduction of BHC in 1949 and Dieldrin in 1950 for the same purpose ${ }^{3}$. These organochloride insecticides also made an important indirect impact in reducing large numbers of intra domestic and peridomestic triatomine bugs, of the Reduviidae family, wherever they were lodged in rural wattle and mud houses ${ }^{12}$. Secondly, as malaria subdued, eradication being certified by the World Health Organization in 1961, an early decision was made in $1952^{4}$ to engage some malaria field workers for house spraying against Chagas disease main vectors: Rhodnius prolixus,
Triatoma maculata and Panstrongylus geniculatus ${ }^{7}$. That initiative not only accounted for a direct and incipient disease control effort, with a substantial contribution against vectorial transmission ${ }^{9}$, but also helped lay ground for the promulgation of a national programme by the Ministry of Health in 1966, with its own budget for the specific control of this disease. This national programme had the specific objectives of limiting vectorial transmission and preventing infections in the younger population. Thirdly, in 1958, a national rural housing programme was launched on a wide scale by the Ministry of Health, offering several different models of standard rural houses, together with piped water and a rural sewage system. This scheme enabled the elimination of thousands of wattle and mud houses and helped to reduce the use of palm leaves, for thatching roofs, walls and animal sheds, which harboured vectors' eggs and thereafter facilitated intra domestic transmission. This paper describes the achievements made by this programme in the reduction of vectorial transmission amongst the general population in almost five decades, in terms of a marked reduction of the house infestation index, house infection index and house density index, a reduced overall population serological percent prevalence in distinct grouped years and a persistent low overall percent prevalence amongst blood donors in all

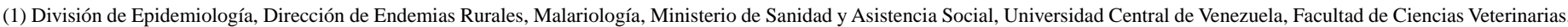
Departamento de Salud Pública, Cátedra de Salud Pública, Maracay, Venezuela.

(2) Departamento de Chagas, División de Epidemiología, Dirección de Endemias Rurales, Malariología, Ministerio de Sanidad y Asistencia Social, Venezuela.

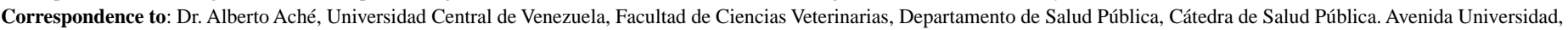
vía El Limón. Apartado Postal 4563, Maracay, Venezuela. Phone/FAX 58.44.631137. E-mail: albache@ cantv.net 
health facilities, both public and private. Active vector transmission remains low and the main endemic areas are confined to piedmonts or higher mountainous regions where coffee is grown.

\section{MATERIAL AND METHODS}

A descriptive epidemiological study was undertaken using available cumulative data from the national Chagas Disease Control Programme (CDCP) archives. A review of entomological rates was condensed from monthly and annual informs of programmes' ongoing surveillance activities, during the period of 1960-1998, by municipality and State. In Venezuela, the municipality constitutes the basic epidemiological unit of measurement for surveillance and vector control activities. The examination of this data included entomological evaluations carried out by house inspections in rural areas, the number and species of bugs captured per house and municipality and examined for the presence of Trypanosoma cruzi; as well as the amount of vector control activities: number of house visits, number of triatomines found per house per man; spraying rounds and the different types of residual insecticides used over time. Human serological data of the rural population corresponding to a "pioneer period" from 1958-1968, accrued from ongoing surveys, served as baseline data. Prevalence rates, expressed as percentages, were determined for subjects testing positive for $T$. cruzi antibodies as numerator data divided by the total number of subjects surveyed corresponding to ten-year age groups and confidence intervals were calculated for each age group as well as for the overall prevalence rate for that period. This process was repeated for the prevalence rates of existing accrued data corresponding to a second period from 1969-1979, which is considered as a "reevaluation period", and which was assembled with the same age groupings as in the previous period. This period was undertaken specifically by the CDCP to measure the impact of previous entomological and serological surveys, as well as control measures, in the same places where control interventions were carried out during the 1958-1968. Finally, a similar procedure was undertaken for two other grouped periods of prevalence rates, again assembled by the same age groupings: one, comprising the years 1980-1989, to be in line with former periods; and a second shorter period, which grouped the years from 1990-1998, to view the seroprevalence trend of ongoing surveys included in many other areas. Records of house infestation and infection indexes, by municipality and State, were accrued for a quantitative and qualitative geographical distribution and mapped. The house and place infestation indexes were calculated as a proportion of the number of houses or places infested by triatomines divided by the number of houses or places examined and multiplied by one hundred. The house and place infection index, expressed as the total number of triatomines with T. cruzi in houses or places, divided by the total number of houses and places examined and multiplied by one hundred. Finally, the house density index, calculated as the number of triatomines captured, divided by the total amount of houses examined. In general, municipalities were subjected to semestral entomological evaluations after house-spraying with insecticides had been completed. During the pioneer period, the number of municipalities that were evaluated annually ranged from 127-143. This range was reduced during the reevaluation period to 125-137; this work load was again lowered to 110-122 during 1980-89; and finally, during $1990-98$ it has been maintained at $15-18$ per year. During this last period, field workers have been reassigned to control activities for malaria and dengue. Notwithstanding, evaluations are now centred in a reduced endemic area.
During the "pioneer period", serological screening for T. cruzi antibodies in populations was done by the complement-fixation test (Machado-Guerreiro), whereas in the following periods, indirect hemagglutination and indirect fluorescent antibody tests were all routinely carried out on subjects together with the first test. By programme standards, a "positive" subject is classified as such when results are positive to two or three tests carried out in parallel; "doubtful" subjects with only one positive of the three tests and who is followed-up over time; a "negative" when all three tests are negative. Ten-year age groups, as filled out by CDCP standard formats, were used for plotting graphs of serological survey data. Existing data in the Department for Blood Banks and Transfusions were reviewed to determine the prevalence for blood donors in all public and private health centres. Screening in blood banks for $T$. cruzi is mandatory by law since 1977 and only persons between the ages of 18 and 60 years are accepted as potential donors. As from 1988, only the ELISA test is used by blood banks for screening. Prior to this year, many other tests were used and also a combination of tests. Prevalence rates were calculated for each year as a percentage of the number of donors that tested positive for $T$. cruzi antibodies between the total number of screened potential donors in all national hospitals and private clinics. Confidence intervals were also calculated for each corresponding year.

\section{RESULTS}

Between 1952 and 1955 accumulated data showed that the general house infestation index had dropped $95 \%$ after some 3,000 houses were sprayed with Dieldrin in small field trials, in a few villages of ten States. From those encouraging results, spraying activities were then increased and $73 \%$ of the total amount of organochlorides so far sprayed were used during the "pioneer period" (Table 1). Also, during 1958-1968, the initial entomological evaluations carried out in more than 14,500 places in 20 States showed that the house infestation index ranged between 60 $80 \%$, the house infection index at $8-11 \%$ and a house density index of $30-50$ triatomine bugs per house. These indexes were respectively reduced during that period to ranges of $0-40 \%, 3-4 \%$ and $10-20$ bugs. By the $1990-98$, the house infestation index had been reduced to $1.6-4.0 \%$, the house infection index ranged $0.01-0.6 \%$ and a house density index was not higher than 3-4 bugs per house.

The endemic area with continuous transmission is now mainly confined to geographical landscapes of piedmonts (500 to 1,500 metres above sea level), as well as patchy foci in mountainous ranges not above 2,300 metres high, situated on a prolongation of the Andean Range and onto the Northern and Central mountain chains. In this area, the main States involved are: Barinas, Portuguesa, Lara, Cojedes, Yaracuy, Falcón, Carabobo, Guárico, Miranda, the Federal District, Anzoátegui and Monagas (Map 1). This region covers $101,488 \mathrm{~km}^{2}, 11.1 \%$ of the national territory; with a total of 168 municipalities and which constitute natural ecotopes for $R$. prolixus. There, this vector is found exclusively in a preferred habitat of palm trees of the Attalea humboltiana species. Low temperatures $\left(16-20{ }^{\circ} \mathrm{C}\right)$ prevail and sustainable market prices favour coffee growing as the main staple. Vector transmission has never been documented in the States of Amazonas, Bolívar and Delta Amacuro. This fact is perhaps due to natural barriers such as the Orinoco river, which separates these federal entities from the mainland States; as well as a predominant sylvatic vegetation, quite distinct from other known biotopes in which predominant abiotic factors play important roles between human ecology and Chagas disease ${ }^{5}$. 
Table 1

Programme interventions by grouped years for the control of Chagas disease

\begin{tabular}{|c|c|c|c|c|c|}
\hline Insecticides & $1952-1955$ & $1958-1968$ & $1969-1979$ & $1980-1989$ & $1990-1998$ \\
\hline \multicolumn{6}{|l|}{ Dieldrin } \\
\hline w.d.p. of $50 \%$ & $170,715 \mathrm{~kg}$. & $630,905 \mathrm{~kg}$. & $221,614 \mathrm{~kg}$. & $83,404 \mathrm{~kg}$. & $7,307 \mathrm{~kg}$ \\
\hline \multicolumn{6}{|l|}{ BHC } \\
\hline w.d.p. of $25 \%$ & - & $205,930 \mathrm{~kg}$. & $257,194 \mathrm{~kg}$. & $11,334 \mathrm{~kg}$. & $2,698 \mathrm{~kg}$ \\
\hline \multicolumn{6}{|l|}{ Lindane } \\
\hline w.d.p. of $25 \%$ & - & $5,324 \mathrm{~kg}$. & - & - & - \\
\hline \multicolumn{6}{|l|}{ Fenitrothion } \\
\hline w.d.p. of $40 \%$ & - & - & - & - & $40,507 \mathrm{~kg}$ \\
\hline e.c. of $50 \%$ & - & - & - & - & $14,314 \mathrm{lt}$ \\
\hline \multicolumn{6}{|l|}{ Propoxur } \\
\hline w.d.p. of $50 \%$ & - & - & - & - & $1,258 \mathrm{~kg}$ \\
\hline e.c. of $25 \%$ & - & - & - & - & $2,295 \mathrm{lt}$ \\
\hline \multicolumn{6}{|l|}{ Deltamethrin } \\
\hline w.d.p. of $25 \%$ & - & - & - & - & $15 \mathrm{~kg}$ \\
\hline e.c. of $25 \%$ & - & - & - & - & $146 \mathrm{lt}$ \\
\hline c.s. of $5 \%$ & - & - & - & - & $122 \mathrm{lt}$ \\
\hline \multicolumn{6}{|l|}{ Lambdacyhalothrin } \\
\hline e.c. of $2.5 \%$ & - & - & - & - & $102 \mathrm{lt}$ \\
\hline Rural houses built & - & 78,645 & 120,283 & 132,880 & 73,426 \\
\hline House modifications & - & 100 & 100 & 1,408 & 12,918 \\
\hline
\end{tabular}

w.d.p.= water-dispersable powder; e.c.=emulsifiable concentration; c.s.= concentrated solution.

An unstable area exists, in which landscapes consist of grasslands with scattered broad-leaved evergreen trees and costal plains, covering about $263,512 \mathrm{~km}^{2}$. Here, T. maculata plays second roles to $R$. prolixus and transmission is low, except for occasional outbreaks with a few acute cases, which have been documented during 1990-98 in the States of Barinas and Portuguesa. In this extended region, it has been observed from time to time, that negative entomological findings can be generated in as much as $27-30 \%$ of the 645 existing municipalities and parishes. Then, in the following evaluations, become positive again with low values for the entomoepidemiological indexes. In any subsequent survey, the sole presence of one bug confers a positive index, which can revert registered negative trends in some cases, according to stringent programme specifications. Increases of the house infestation index in some municipalities may be attributed to temporary abundance of vector populations during the rainy season, when higher numbers are usually found, and which are detected by routine entomological evaluations; or by an increase of wattle and mud houses, hence of vector population, when new human invasions occur as a consequence of coffee growing. Also, on account of periodic shortcomings of ongoing vector control activities due to financial cutbacks, labor problems or a lack of collaboration by some communities. However, by and large, bugs are no longer seen in abundance in this unstable region as in previous years and the global house infestation index ranked between 0.5 and $4 \%$ as detected by ongoing surveillance activities.

During the "pioneer period" the vectors that were found in houses, in different proportions, covered an area which totaled $750,000 \mathrm{~km}^{2}$ or $81 \%$ of the national territory. That has been reduced to approximately $365,000 \mathrm{~km}^{2}$. Of an estimated six million persons at risk during the 1980 's, this population has now declined to near four million, $18.3 \%$ of the national population estimated at $21,734,964$ inhabitants.

During the 1990-98 period entomological evaluations declined to an average of 18 municipalities per year. Important factors for this declination can be attributed to: a) progressive reduction of funds from the central government for programme activities; b) rapid political decentralization, which has imposed the reorganization of regional health services, putting surveillance activities for Chagas disease on a very low priority basis in many States; c) emphasis from central health authorities to dismantle existing vertical programmes, like the CDCP, and incorporating them into the general health services regionally with the subsequent weakening of field activities; finally, d) the reemergence of dengue nation-wide and the upsurge of malaria in six States have caused the divergence of field workers from other programmes to the control of these two diseases. Notwithstanding, serological monitoring increased during that period and the overall rural seroprevalence rate has declined 


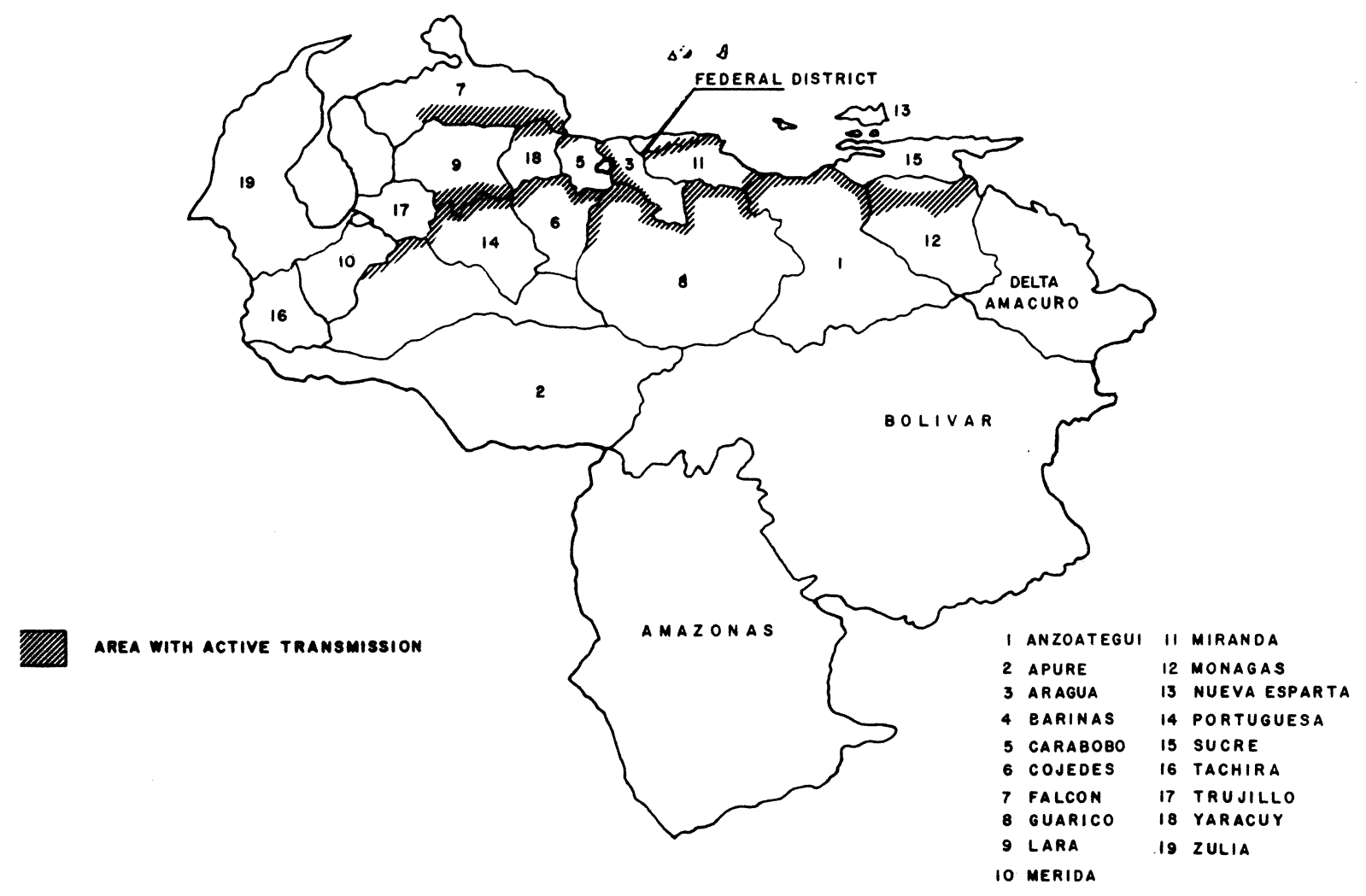

Map 1 - Chagas' disease endemic area - Venezuela.

Table 2

Seroprevalence by age and time periods

\begin{tabular}{|c|c|c|c|c|c|c|c|c|c|c|c|c|c|c|c|c|}
\hline \multicolumn{17}{|c|}{ YEARS } \\
\hline \multirow[t]{2}{*}{ AGE } & \multicolumn{4}{|c|}{$1958-68$} & \multicolumn{4}{|c|}{$1969-79$} & \multicolumn{4}{|c|}{$1980-89$} & \multicolumn{4}{|c|}{ 1990-98 } \\
\hline & $\mathrm{N}$ & pos & $(\%)$ & 95\% C.I. & $\mathrm{n}$ & pos & $(\%)$ & 95\% C.I. & $\mathrm{n}$ & pos & $(\%)$ & 95\% C.I. & $\mathrm{n}$ & pos & $(\%)$ & 95\% C.I. \\
\hline $0-9$ & 1,337 & 274 & 20.5 & $(18.3-22.7)$ & 6,123 & 244 & 3.9 & $(3.5-4.5)$ & 23,569 & 259 & 1.1 & $(0.9-1.2)$ & 35,494 & 174 & 0.5 & $(0.42-0.56)$ \\
\hline $10-19$ & 3,793 & 1,077 & 28.4 & $(26.9-29.8)$ & 3,144 & 314 & 9.9 & $(8.9-11.0)$ & 22,277 & 535 & 2.4 & $(2.2-2.6)$ & 26,951 & 493 & 1.8 & $(1.6-2.0)$ \\
\hline $20-29$ & 1,860 & 910 & 48.9 & $(46.6-51.2)$ & 1,078 & 320 & 29.6 & $(26.9-32.5)$ & 9,845 & 1,201 & 12.4 & $(11.5-12.8)$ & 13,518 & 806 & 5.9 & $(5.5-6.3)$ \\
\hline $30-39$ & 1,676 & 1,046 & 62.4 & $(60.0-64.7)$ & 782 & 282 & 36.1 & $(32.6-30.5)$ & 7,280 & 1,936 & 26.6 & $(25.5-27.6)$ & 10,469 & 1,691 & 16.1 & (15.4-16.8) \\
\hline $40-49$ & 1,351 & 892 & 66.0 & $(63.4-68.5)$ & 818 & 403 & 49.2 & $(45.7-52.7)$ & 5,487 & 2,058 & 37.5 & $(36.2-38.8)$ & 6,982 & 1,978 & 28.3 & $(27.2-29.4)$ \\
\hline $50+$ & 1,235 & 803 & 65.0 & $(62.2-67.6)$ & 1,163 & 478 & 41.1 & $(38.2-43.9)$ & 10,066 & 4,832 & 48.0 & $(47.0-48.9)$ & 10,242 & 4,406 & 43.0 & $(42.1-43.9)$ \\
\hline Total & 11,252 & 5,002 & 44.5 & $(43.5-45.3)$ & 13,108 & 2,041 & 15.6 & $(14.9-16.2)$ & 78,524 & 10,821 & 13.7 & $(13.5-14.0)$ & 103,656 & 9,548 & 9.2 & $(9.0-9.4)$ \\
\hline
\end{tabular}

n: number of subjects ; pos: seropositive ; \%:percent ; 95\% C.I. : $95 \%$ Confidence Interval.

from $44.5 \%$ (95\% C.I.: $43.4-45.3 \%$ ) to $9.2 \%$ (95\% C.I.: $9.0-9.4 \%$ ) for successive grouped periods from 1958 to 1998 (Table 2). The decline in the percent seroprevalence through successive age-groups, equally for genders, following year-periods, suggesting a constant age selection in successive cohorts (Figure 1). The frequency and extent of exposure to T. cruzi infections in early life have decreased progressively throughout these year-periods showing a cohort effect. This can be attributed to programme intervention factors over time: intradomestic spraying with residual insecticides, building of rural houses and the modification of wattle and mud houses. On the other hand, the higher percent seroprevalence observed from forty years of age and beyond does not represent higher risk groups, but rather a reflection of the residuals of higher infection rates in early life when this population did not benefit from programme interventions.

The overall blood donor seroprevalence has been descending gradually from more than $2 \%$ to less than $1 \%$ between 1984-98 (Table 3 ). In years previous to 1988 , serological screening in blood banks was 


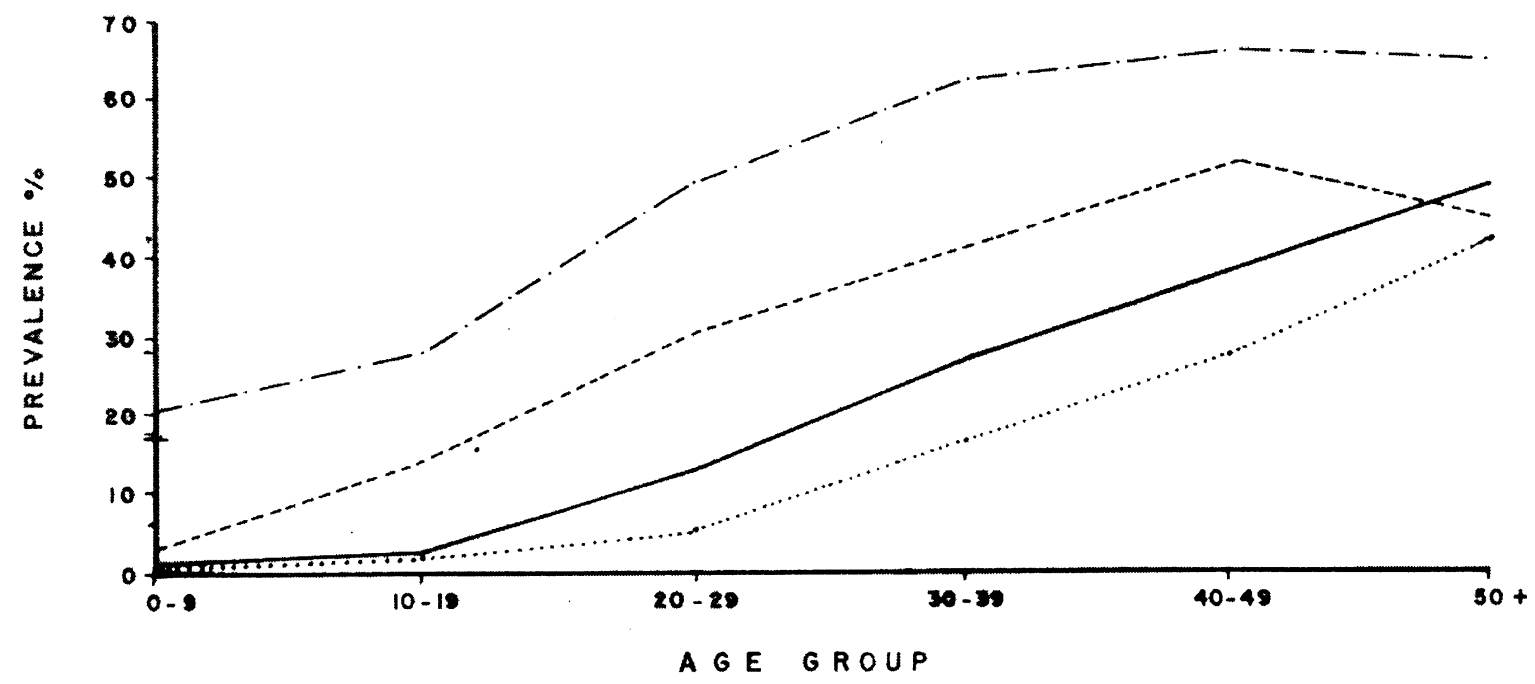

TIME PERIODS

$1958-1968 \cdot-.-\ldots$.

$1969-1979-. .-1-1-1$

$1980-1989-$

$1990-1998$

Fig. 1 - Chagas disease prevalence rates according to age - Venezuela - 1958-1998.

Table 3

Chagas Disease Control Programme

Seroprevalence for T. cruzi infections in blood donors for all health centres in Venezuela 1984 - 1998

\begin{tabular}{ccc}
\hline Year & $\mathrm{N}$ & Prevalence $(\%)$ \\
\hline 1984 & 170,553 & 1.94 \\
1985 & 230,309 & 1.50 \\
1986 & 187,589 & 1.84 \\
1987 & 231,620 & 1.37 \\
1988 & 223,067 & 1.38 \\
1989 & 154,081 & 1.13 \\
1990 & 252,090 & 1.09 \\
1991 & 251,744 & 1.10 \\
1992 & 205,574 & 1.35 \\
1993 & 204,316 & 1.32 \\
1994 & 206,517 & 0.83 \\
1995 & 202,515 & 0.84 \\
1996 & 266,828 & 0.77 \\
1997 & 262,462 & 0.77 \\
1998 & 262,295 & 0.78 \\
\hline
\end{tabular}

carried out by different methods in private and public health centres. After that year until presently, only the ELISA technique has been used. However, these yearly overall percentages are far below the average estimate of $6 \%$ seroprevalence in some blood banks in the early 1960's'. Unfortunately, a number of false negatives results can be generated by cross-reactions to Leishmania. Leishmaniasis is also endemic in most areas where Chagas disease is detected. However, this possibility may be avoided by use of the indirect hemagglutination which is routinely used by the $\mathrm{CDCP}^{14}$. In particular, only the States of Portuguesa $(5.1 \%)$ and Cojedes $(2.7 \%)$ exhibited the higher percentages with regards to these national averages in the last ten years. In these States it is usual to detect persons with combined infections of $T$. cruzi and $T$. rangeli by parasitological tests and this is probable reflected also by the ELISA assay.

While spraying houses and peridomestic sheds, with organochloride insecticides, have been the mainstay for vector control (Table 1), it has always been considered as a measure of temporal control. Of the total amount of organochlorides used during almost fifty years, 52.7\% $(842,159 \mathrm{~kg})$ were sprayed during the "pioneer period". Although this intervention helped to reduce the densities of vector populations, the use of these products diminished as the construction of rural houses increased in the following periods. The house construction of standard rural houses with three bedrooms, toilet, porch and a washing place, had a more lasting effect on vectorial control since it minimized potential house infestation. As the endemic areas decreased in time, insecticide spraying also was reduced in general. The manufacture of organochlorides has been discontinued in recent years and they have been substituted by synthetic pyretroids. From 1959 to 1998 , a total number of 417,234 rural houses have been constructed to attend a population of $2,165,778$ inhabitants. While very few modifications of wattle and mud houses had been undertaken in the first periods, much effort has been put into the latest period of 1990-98, when almost 13,000 modifications have been completed (Table 1). House modification depends much on the acceptance of individual households, as well as communities' participation, to improve structures used as homes that have cracked and holed walls, as well as palm roofs. This process has been quite slow amongst the exposed population due to a number of complex socio- 
cultural and economic factors, as well as unawareness of the long-term consequences of the disease ${ }^{13}$.

\section{DISCUSSION}

Chagas disease control programme entomological parameters, as well as the general population serological percent prevalence and blood donors annual prevalence rates, indicate that vector transmission of Chagas disease has declined substantially in Venezuela after nearly five decades of control activities. This reduction in transmission can be attributed to the combined effects of ongoing entomoepidemiological surveillance, continuous house spraying with residual insecticides and the concurrent building and modification of rural houses in endemic areas. The massive use of organochloride residual insecticides during the "pioneer period" and thereafter made an important initial impact in lowering prevalence rates found in children. Additional protection has been provided by the extended construction of rural houses as a more permanent and sustained solution to vector transmission of the disease by Rhodnius prolixus ${ }^{8}$. By and large, programme objectives have been attained since these measurable changes indicate that not only generations have been spared from $T$. cruzi infections, but also that major contributions have been made in primary and secondary prevention of the disease. Active transmission is now confined to geographical landscapes of piedmonts and mountainous areas where coffee growers are the major socioeconomic group at risk. The general population at risk has diminished almost $58 \%$ and the number of newly infected persons with Trypanosoma cruzi has dwindled significantly ${ }^{1}$.

However, an unstable region still exists with low transmission potential in costal plains and grassland landscapes. Here, infestation rates vary broadly from nearby places and can fluctuate constantly in time from negative results to low percentages. Some of these areas, where transmission has been interrupted, can suddenly be reclassified as being positive due to the finding of a sole bug in peridomestic or domestic settings, even if temporarily attracted by houselights from zootic environments ${ }^{16}$, in line with stringent programme requirements. Also, cultural and socioeconomic factors contribute in maintaining these unstable regions since exposed communities harness no protection against vectors; and on the other hand, there are no specific laws to avert human invasions of these landscapes, mainly by neglected social groups, for agricultural activities.

Since incidence rates are difficult to obtain accurately for Chagas disease, on account of limitations in diagnosis: less than $10 \%$ of patients are symptomatic and it is difficult to detect $T$. cruzi with parasitological tests; therefore comparisons have been limited to prevalence rates. These rates are statistically more stable and very useful for programme objectives. However, they may be biased if severities of the illness or longevity of patients differ geographically or due to influences such as variations in levels of ascertainment; variations in diagnostic criteria; and variations in population structure, as well as appreciable population migration. With regards to these factors, it must first be stated that Venezuela has maintained a larger under 30 years of age population structure during this observed period from 1950 to 1998. In rural areas, this higher risk age group has slowly declined from 72 to $67 \%$ in successive population censuses from 1950 up to $1991^{17}$. No vast changes in population structure, on account of social upheavals, has occurred during that time to bias the observed downward trend in prevalence rates over time. Even if large numbers had migrated to major cities twenty years previously to the $1980 \mathrm{~s}$, it is this particular age group that has benefited largely by control efforts throughout the grouped periods. Secondly, since only one serological method (Machado-Guerreiro) was used during the "pioneer period" and three methods later on by a central laboratory; with all tests being carried out by a limited number of trained technicians; this makes diagnostic criteria more unlikely to have varied largely considering that these procedures were standard assays, but certainly with some degree of difficulty in their accomplishment. In addition, potential ascertainment biases are reduced since standard field screening procedures have been carried out using the blot filter paper method, whereby continuous massive blood samples have been taken of the general population, with a traditionally acceptable degree of collaboration in all States. Thirdly, whilst important migration movements had been registered in all States, during the early 1960's and between the years $1970-1980^{6}$, made up of young rural people moving into urban areas, these migratory populations did not increase the number of registered annual deaths attributable to this disease; even after an average minimal latent period of 10 to 15 years had elapsed from presumed exposure in previous rural settings. Again, on the other hand, potential blood donors from these populations did not reflect higher annual seroprevalence rates detected in blood banks of all health centres as from 1984. Whether they were recent migrants, or were required to donate blood on emergency calls from some risk areas or urban areas, or screened on entrance to the armed forces for military duty, in the last twenty to thirty years; still, the general low annual rates indicate that successive cohorts of donors had benefited from earlier interventions against the disease in previous decades. Fourthly, low prevalence rates are still being registered by continuous monitoring of the remaining rural population in the following years. Finally, from studies carried out in the State of Portuguesa $^{2}$ where the overall prevalence rates have been higher than other States, as well as in blood banks, it appears that severity of illness has not been strikingly different from the rest of other States in terms of clinical symptoms, cardiographic abnormalities or clinical outcome.

It is quite possible that $R$. prolixus can be significantly reduced in the unstable area, as well as in the higher risk endemic area, in the coming years. While integrated control has long been advocated, rapid entomoepidemiological evaluations, with community participation, are in earnest demand for speedy focal interventions, by programme managers and the affected communities. In the advent of continuous dwindling health budgets, extensive ongoing entomological evaluations have been seriously affected. Notwithstanding, faced with this reality, Venezuela was granted a five-year loan from the World Bank in 1995 to fund surveillance activities for an array of infectious diseases which includes Chagas disease. By and large, dengue has become the major national public health problem and less attention has been given to Chagas disease. It is hoped that these long-term achievements will not be lost in the near future and that full political commitment, both national and regional, will continue to back further interventions for the elimination of Chagas disease.

\section{ACKNOWLEDGMENTS}

Our heartened acknowledgments to Luis Borgas, Helen Gómez, Ornelio Rojas, Jesús Barrios and Nancy Rondón for the drawing of the map and figure. Roberto Torres for his dedication in helping us to find the data on the amount and types of insecticides used for vector control. 
Violeta Pérez for providing the annual amount of rural houses built and global costs. Luis Segovia for data on rural house modifications. Mauricio Salazar for the information provided from the Department of Blood Banks and Transfusions. Jorge Arias, of PAHO/WHO-Venezuela, for his critical assessment of this paper.

\section{RESUMO}

\section{A interrupção da transmissão da doença de Chagas na Venezuela}

A interrupção da transmissão da doença de Chagas é atribuida aos efeitos conjuntos da vigilância soroepidemiológica, borrifação contínua de inseticidas residuais assim como a construção e modificação de casas rurais nas áreas endêmicas nas últimas cinco décadas. Os $750.000 \mathrm{~km}^{2}$ originais da área endêmica foram reduzidos a $365.000 \mathrm{~km}^{2}$. Durante os anos 1958 a 1968, avaliações entomológicas iniciais indicaram que o índice de infestação domiciliar variava de 60 a 80\%, o índice de infeção domiciliar entre 8 e $11 \%$ e o índice de densidade domiciliar de 30 a 50 triatomíneos por casa. Para o período 1990 a 1998 estes índices foram respectivamente reduzidos para 1,6 a $4,0 \%, 0,01$ a $0,6 \%$ e $3-4$ triatomíneos por casa. A soroprevalência geral diminuiu de 44,5\% (95\% I.C.: 43,4 a 45,3) para 9,2\% (95\% I.C.: 9,0 a 9,4\%) entre 1958 a 1998. A prevalência da infecção pelo Trypanosoma cruzi entre os doadores de sangue encontra-se abaixo de $1 \%$. A população sob risco de infecção tem sido estimada em menos de quatro milhões de pessoas. Tendo em vista que as taxas de prevalência são estáveis e apropriadas para a avaliação de programas de saúde pública, atenção tem sido dada para tendências potenciais que poderiam alterar o sentido dos resultados tais como: diferenças geográficas na doença ou na longevidade dos pacientes; variações nos níveis de determinação; variações nos critérios de diagnóstico; e variações nas estruturas populacionais, assim como migrações significantes de populações. As áreas endêmicas com transmissão contínua estão restritas a sopés de montes e focos isolados em áreas montanhosas, onde o vetor exclusivo é Rhodnius prolixus. Existem ainda áreas onde a transmissão é muito baixa e ocorrem surtos ocasionais com poucos casos agudos notificados nos estados de Barinas e Portuguesa.

\section{REFERENCES}

1. ACHÉ, A. - Programa de control de la enfermedad de Chagas en Venezuela. Bol. Direcc. Malar., 33: 11-22, 1993.

2. ACQUATELlA, H.; CATALIOTI, F.; GÓMEZ-MANCEBO, J.R.; DÁVALOS, V. \& VILLALOBOS, L. - Long-term control of Chagas disease in Venezuela: effects on serologic findings, electrocardiographic abnormalities and clinical outcome. Circulation, 76: 556-562, 1987.
3. BERTI, A.L.; GABALDON, A. \& CARRILLO, S.J. - Modernos insecticidas de acción remanente. Rev. Ingeniería sanit., 10: 53-58, 1956.

4. BERTI, A.L.; GÓMEZ-NUÑEZ, J.C.; GUERRERO, L. \& GARCÍA-MARTÍN, G. Conversión de la campaña de erradicación de la malaria en profilaxis de la Enfermedad de Chagas. Rev. Sanid. Asist. soc., 26: 24-32, 1961.

5. CARCAVALLO, R.U. - Ecología humana y enfermedad de Chagas. II. Factores abióticos del ambiente. Bol. Direcc. Malar., 19: 39-43, 1979.

6. CHEN, CHI-YI. - Movimientos migratorios en Venezuela. Caracas, Pub. Inst. Invest. Econo. Univ. Católica Andrés Bello, 1968.

7. COVA-GARCÍA, P. \& SUÁREZ, M. - Estudio de los triatominos en Venezuela. Caracas. Ministerio de Sanidad y Asistencia Social, 1959. (Publ. Div. Malar. No. 11).

8. GAMBOA, J. \& PÉREZ RÍOS, L.J. - El "Rancho" Venezolano: su influencia el la prevalencia triatomina doméstica. Bol. Direcc. Malar., 5: 129-140, 1965.

9. GUERRERO, L.; DOMÍNGUEZ-QUESADA, M.; GARCÍA-MARTÍN, G. \& BORGES, L. - Estado actual de la campaña contra la enfermedad de Chagas en Venezuela. Arch. venez. Med. trop. Parasit. méd., 5: 219-265, 1965.

10. MAEKELT, G.A. - Aspectos seroepidemiológicos de la enfemedad de Chagas en Venezuela. Arch. venez. Med. trop. Parasit. méd., 5: 95-105, 1973.

11. MINISTERIO DE SANIDAD Y ASISTENCIA SOCIAL - Anuario de epidemiología y estadística vital. Venezuela, MSAS, 1980-1996.

12. PIFANO, F.; MAEKELT, A. \& ANSELMI, A. - Estado actual de la enfermedad de Chagas en Venzuela. Rev. venez. Sanid., 26: 17-24, 1961.

13. PINTO DIAS, J.C. - Aspectos socio-culturales y económicos relativos al vector de la enfermedad de Chagas. In: Factores biológicos y ecológicos en la enfermedad de Chagas. Argentina, Publ. Org. Panam. Salud \& Min. Salud y Acción Social, 1985. v. 2, p. 289-304

14. SCHMUÑIS, A.G. - Trypanosoma cruzi, the etiologic agent of Chagas' disease: status in the blood supply in endemic and nonendemic countries. Transfusion, 31: 547-557, 1991.

15. TEJERA, E. - La Trypanosomose américaine ou maladie de Chagas au Vénezuéla. Bull. Soc. Path. exot., 12: 509-513, 1919.

16. TONN, R.J.; ESPÍNOLA, H.; MORA, E. \& JIMÉNEZ, J.E. - Trampa de luz negra como método de captura nocturna de triatominos en Venezuela. Bol. Direcc. Malar., 18: 25-30, 1978.

17. VENEZUELA - Estimaciones y proyecciones de población 1950-2035. Caracas, Oficina Central de Estadística e Informática, 1995.

Received: 04 May 1999

Accepted: 17 July 2000 